\title{
The Potential Use of Probiotics to Improve Animal Health, Efficiency, and Meat Quality: A Review
}

\author{
Sarmad G. Al-Shawi ${ }^{1}$, David S. Dang ${ }^{2}$, Asraa Y. Yousif ${ }^{3}$, Zena K. Al-Younis ${ }^{1}$, Teif A. Najm ${ }^{2}$ (] \\ and Sulaiman K. Matarneh ${ }^{2, *}$ \\ 1 Food Science Department, Agriculture College, Basrah University, Basrah 00964, Iraq; \\ sarmad.mohammed@uobasrah.edu.iq (S.G.A.-S.); zena.issa@uobasrah.edu.iq (Z.K.A.-Y.) \\ 2 Department of Nutrition, Dietetics and Food Sciences, Utah State University, Logan, UT 84322, USA; \\ ds.dang24@gmail.com (D.S.D.); taefnajeem@yahoo.com (T.A.N.) \\ 3 Animal Production Department, Agriculture College, Basrah University, Basrah 00964, Iraq; \\ asraa.yousif@uobasrah.edu.iq \\ * Correspondence: sulaiman.matarneh@usu.edu; Tel.: +1-435-797-2114
}

Received: 28 August 2020; Accepted: 29 September 2020; Published: 1 October 2020

\begin{abstract}
To address the rapidly growing use of probiotics in animal agriculture, this review discusses the effect of probiotics on animal growth and development, immune response, and productivity. Several benefits have been associated with the use of probiotics in farm animals, such as improved growth and feed efficiency, reduced mortality, and enhanced product quality. While the mechanisms through which probiotics induce their beneficial effects are not well understood, their role in modifying the gastrointestinal microbiota is believed to be the main mechanism. The use of probiotics in fresh and fermented meat products has been also shown to reduce pathogenic and spoilage microorganisms and improve sensory characteristics. Although many benefits have been associated with the use of probiotics, their effectiveness in improving animal performance and product quality is highly variable. Factors that dictate such variability are dependent on the probiotic strain being utilized and its stability during storage and administration/inoculation, frequency and dosage, nutritional and health status as well as age of the host animal. Therefore, future research should focus on finding more effective probiotic strains for the desired use and identifying the optimum dose, administration time, delivery method, and mechanism of action for each strain/host.
\end{abstract}

Keywords: probiotic; gut microbiota; immune response; growth; efficiency; meat quality

\section{Introduction}

The increase in demand for animal products due to the growing world population has been an ongoing challenge for the animal production sector worldwide [1]. Tremendous progress has been achieved over the past five decades in this regard, mainly due to improvements in genetic selection, health status, nutrition, and the use of antibiotics and growth promotants [2]. Indeed, the use of the latter two practices in commercial animal production has improved the health status and feed efficiency of farm animals, which has led to approximately $18 \%$ increase in the overall growth performance [3]. However, the use of antibiotics and growth promotants has brought about concerns over the development of antibiotic resistant microbes [4], increase in foodborne allergies [5], and the negative impacts it has on the environment such as agricultural runoff [6]. Furthermore, although still debated, there is a rising concern among increasingly wary consumers on the effects of antibiotics and growth promotants on human health [7]. To that end, researchers have been investigating alternative ways to improve the quantity, quality, and homogeneity of farm animals and their products. One such alternative is the supplementation of probiotics, as single or mixed strains, to the diet of farm animals. 
The term "probiotic" was coined by Metchnikoff in 1908 and derived from the two Greek words "pro" and "bios", which means "for life" [8]. Probiotics are defined as living microbial supplements that advantageously influence the host through improving its intestinal microbial composition [9]. A more modern definition was adopted by FAO/WHO in 2002 [10], which states "mono or mixed strains of living microorganisms which confer a desirable health benefits on the host when used adequately". To regard a microorganism as probiotic, it should be nonpathogenic, able to give a viable cell count, has a positive effect on the health of the host, and enhance the functions of the intestinal tract. The most commonly used probiotics are Lactobacillus acidophilus, Lactobacillus lactis, Lactobacillus plantarum, Lactobacillus bulgaricus, Lactobacillus casei, Lactobacillus helveticus, Lactobacillus salivarius, Bifido bacterium spp., Enterococcus faecium, Enterococcus faecalis, Streptococcus thermophilus, Escherichia coli bacteria, and other probiotic fungi such as Saccharomyces cerevisiae and Saccharomyces boulardii [11,12]. Decades of research have indicated that the use of probiotics in farm animals is beneficial as it improves feed efficiency, weight gain, and immune response $[13,14]$. However, the overall effectiveness of probiotics is dictated by factors such as optimal selection of microbial strains, the use of a suitable dose, and the species and age of the host $[15,16]$. Thus, careful consideration must be taken prior to any implementation of probiotics in the diet of farm animals. The aim of this review is to discuss the administration of probiotics in animal feed, either as supplements or additives, and their effect on animal health, growth and productivity, and product quality. We will also briefly review the use of probiotics in fresh and fermented meat products.

\section{The Gut Microbiota}

Within the gastrointestinal tract (GIT) of animals, there exists a microbial population that is widely diverse [17]. Microbial density and diversity vary throughout the GIT, with maximal populations in areas where the $\mathrm{pH}$ range is close to neutral $[17,18]$. Such areas include the pre-gastric rumen of ruminants and post-gastric cecum of ruminants, horses, pigs, and fowls. Depending whether the animal is a ruminant or monogastric, the GIT can sustain up to several thousand unique microbial species including bacteria, archaea, fungi, and protozoa [19]. Because bacterial species are the most commonly used microorganisms as probiotics [20], we intend to focus our review to bacteria.

Most gut bacteria belong to two main phyla, Firmicutes and Bacteroidetes, but species from the phyla Actinobacteria, Proteobacteria, and Verrucomicrobia are also present [21,22]. For instance, Firmicutes and Bacteroidetes species account for approximately $99 \%$ (42\% and $57 \%$, respectively) of the total microbiota in bovine rumen [23], and $96 \%$ (49\% and $47 \%$, respectively) in ovine rumen [24]. However, Firmicutes are predominant in the hindgut of pigs and cecum of chickens, with only a small percentage $(<2 \%)$ of Bacteroidetes [25]. The commensal (indigenous) gut microbiota plays important roles in the animal's overall health, growth and development, and productivity through promotion of immune system development and response and facilitating nutrient extraction from the diet [26]. The latter is obvious in ruminant animals as the gut microbiome provides approximately $70 \%$ of their daily energy requirements [27]. A large proportion of that percentage comes from microbial fermentation of carbohydrates, which generates volatile fatty acids that are absorbed and used as an energy source. Moreover, the microbial populations themselves can be utilized as a source of protein (microbial protein) as they leave the rumen and are digested in the small intestine [28].

The gut microbiota is known to interact with the host immune system [29]. However, communication between the two "systems" is indirect and relies on intestinal epithelial cells residing in the lumen and immunomodulatory cells in the lamina propria $[29,30]$. The microbiota and immune cells are separated by an intestinal epithelium that has two essential functions. The first is to physically segregate any foreign substances or microbes from the host immune cells. The second is to deliver signals to immune cells in response to metabolites produced by the gut microbiome, which, in turn, invokes an immune response [31]. Thus, the relationship between the gut microbiota and the host's health is complex as it involves "cross-talk" between the residing commensal microbiota, epithelium, and innate immune system. 
Sustaining an abundant and diverse microbiota is beneficial to the animal's welfare [32]. An "imbalanced" microbiota (dysbiosis) in which the population of pathogenic bacteria is higher than beneficial commensal bacteria, leads to impairment of gut health, and ultimately, overall health, behavior (feeding, social, and stress response), and growth of an animal [25]. Several factors are known to influence the enrichment and diversification of the microbiota, including diet, environment, and host genetics [33]. The relationship amongst these three factors is complex, as one factor could be more influential than other, depending on the circumstances. For instance, the GIT of a newborn animal is "sterile" right after birth, but is rapidly colonized by microbial communities from the environment and the mother $[33,34]$. In an example where a change in diet modulates gut microbiota, Hildebrandt et al. [35] observed an increase in the phyla Firmicutes and Proteobacteria and a decrease in Bacteroidetes in mice that were fed a high fat diet. Although studies have shown that genetics also contributes to modulating the microbiota [33,36,37], its contribution is likely confounded with environmental and dietary factors [33]. In addition to the aforementioned, the use of probiotic supplementation is known to diversify and modulate the gut microbiome [38]. It has been shown that probiotics can enrich and restore beneficial commensal microbes during a period of dysbiosis [39]. However, one of the challenges in the use of probiotics is determining when the appropriate modification should be implemented during the lifecycle of an animal. Some have argued that the intervention to modify the microbiome should occur when the animal is young, because changes in the microbiome during adulthood are rather subtle $[40,41]$. Thus, the effectiveness of probiotic on the gut microbiota is closely related to the time of implementation, such as during the weaning, growing, or finishing stages of growth [42].

\section{Proposed Mechanism of Action for Probiotics}

The use of probiotics for animals has been increasing since the mid-1970s [43]. Probiotics have been used as therapeutic supplements in farm animals in order to decrease morbidity and mortality [44], improve feeding behavior [45], and increase production (meat, milk, and eggs) yield $[44,46]$. Furthermore, due to their ability to inhibit a wide variety of pathogenic microorganisms, derived from the environment and diet, the use of probiotics has expanded into the food industry as well $[38,47]$. There are at least two proposed mechanisms by which probiotics can combat unwanted microorganisms: the production of inhibitory compounds and/or direct cell-to-cell interactions [48]. Probiotics produce antimicrobial compounds, such as organic acids, hydrogen peroxide, bacteriocins, and biosurfactants, all of which can inhibit the growth of pathogenic microorganisms [49]. The most commonly produced compounds by probiotic bacteria are lactic and acetic acids that reduce the $\mathrm{pH}$, thereby making it less favorable for pathogen growth. Additionally, probiotics enhance resistance to intestinal pathogens via competitive colonization of intestinal adhesion sites and nutrients [50,51].

Probiotics, like other organic nutrients in the intestine, are partly digested and broken down, thus, only a small population is viable. Yet, probiotics have shown to be effective against microorganisms that negatively impact the host's health. Systemic stimulation of the immune system is an important role for probiotics against the pathogenic invading microorganisms [52]. Probiotics are suggested to participate in a complex stimulatory mechanism of the innate immune system through increasing expression of toll-like receptors (TLRs), which results in the release of cytokines such as tumor necrosis factor- $\alpha$ (TNF- $\alpha$ ), interleukin-4 (IL-4), and interferon- $\gamma$ (IFN- $\gamma$ ) [53]. In this regard, the intake of probiotics has been shown to improve disease resistance and reduce metabolic stress and mortality $[13,54]$. A plain diet supplemented with a mixture of probiotics containing Lactobacillus casei, Lactobacillus acidophilus, Bifidobacterium thermophiles, and Enterococcus faecium increased the concentration of immunoglobulins (Ig) M and $G$ in turkeys, which enhanced their resistance against diseases as well as growth performance [55]. Moreover, an increase in intestinal IgA of sows and piglets supplemented with Bacillus cereus for 56 days at $2.6 \times 10^{5}$ and $1.4 \times 10^{6} \mathrm{cfu} / \mathrm{g}$ of feed, respectively, was also reported [56]. Secretion of mucosal IgA prevents microorganisms and toxins binding to epithelial cells, a mechanism known as immune exclusion [57]. In a different study, Yi et al. [58] showed 
that the dietary administration of Bacillus velezensis JW in fish (Carassius auratus) increased the activity of several enzymes involved in immune response such as acid phosphatase, alkaline phosphatase, and glutathione peroxidase in serum, as well as expression of regulatory cytokine genes including TNF- $\alpha$, IFN- $\gamma$, and IL-1, 4, and 10 in head kidney. In addition, the same study showed that when challenged with a pathogenic bacterium, Bacillus velezensis JW-supplemented fish had improved survival rate.

One of the most widely used probiotics are Lactobacillus cultures, which have been shown to control gastrointestinal pathogenic microbial populations [59]. A variety of Lactobacillus strains are effective in decreasing Escherichia coli, Salmonella, and coliform counts in poultry [60-64], and Clostridium sp. in piglets [65]. In beef cattle, feeding $10^{9} \mathrm{CFU}$ of Lactobacillus acidophilus NP51 per day to steers for 126 days was shown to reduce E. coli O157:H7 shedding by 37\% [66]. Further, the use of Lactobacillus rhamnosus has been shown effective against a virulent strain of Aeromonas salmonicida in aquaculture [67]. The reduction of pathogenic microbes in the gut by Lactobacillus is usually attributed to its ability to exclude other microorganisms by competing for adhesion sites and nutrients [68]. For a more in-depth review on the mechanisms involved in competing for adhesion sites, please refer to relevant reviews by Lebeer et al. [69] and Vélez et al. [70]. In totality, the use of probiotics seems to improve the health and immune system function of farm animals.

\section{Application of Probiotics in Animal Growth and Production}

There are several factors that can dictate the growth of an animal such as genetics, age, diet, and sex [71]. Among those factors, providing an adequate nutritional plane is essential for the growth and development of an animal [72]. Not only does an animal require optimal amount of feed, but also improving the digestibility of feedstuff is crucial for maximizing growth. Meng et al. [73] reported an increase in growth performance of growing and finishing pigs that were supplemented with the probiotics Bacillus subtilis and Clostridium butyricum. The increase in growth performance was attributed to better nutrient digestibility in the probiotic supplemented pigs compared to their control counterparts. Similarly, greater nutrient absorption was observed in pigs that were supplemented with a strain of Bacillus culture [74]. In this case, after four to five months of supplementation, pigs that received the probiotic showed a $10 \%$ increase in protein utilization compared to pigs that did not receive any supplementation. Improved weight gain and performance was also reported in broiler chicks [75-78] and calves [79,80] when supplemented with probiotics. Abdel-Azeem [45] indicated that turkeys supplemented with Bacillus amyloquefaciens experienced increased feeding frequency and duration. Although the exact mechanism is still unclear, more recent research on the relationship between the gut microbiome and the brain (the gut-brain axis) have indicated the possibility of neurological changes occurring in which the microbiota could affect the feeding behavior of farm animals [25].

One of the biggest challenges to overcome in advocating the use of probiotics is their effectiveness and reliability in comparison to antibiotic growth promoters and implants. Ran et al. [81] demonstrated that steers that were given implants alone or in combination with antibiotics had approximately $10 \%$ more growth than those given a supplement containing fermented Lactobacillus products. Although several studies have reported positive effects on growth and performance from the use of probiotics, the efficacy of probiotics must be taken with great consideration. This is because the efficacy of probiotics is influenced by many factors such as differences in microbial composition (e.g., single or multi-strains) and viability, method of administration and dosage, environmental stress factors, as well as animal's age and health status. For example, Zhang et al. [82] reported no improvement in average daily gain, dry matter intake, and nutritional digestibility in Holstein calves supplemented with Lactobacillus plantarum GF103 and Bacillus subtilis. The authors suggested that the efficacy of the probiotics was hindered as all calves used in the study were healthy, a notion that has been supported by other studies [83,84]. Table 1 lists the results of recent studies on the effect of probiotics on growth and performance of farm animals. The table also provides information on strain, dosage, and duration of probiotic treatment which is essential for improving the effectiveness of probiotics. 
Table 1. Effects of probiotics on growth and performance of farm animals.

\begin{tabular}{|c|c|c|c|c|c|c|}
\hline Host & Host Age & Probiotic Strain & Administration/Dosage & Duration & Outcome & Ref. \\
\hline Broiler & $\begin{array}{c}\text { Chicks } \\
\text { (1 day old) }\end{array}$ & $\begin{array}{c}\text { Mixed: } \\
\text { B. subtilis (CPB 011, CPB } \\
\text { 029, HP 1.6, and D014) } \\
\text { B. velezensis (CBP 020 } \\
\text { and CPB 035) }\end{array}$ & $1 \times 10^{9} \mathrm{CFU} / \mathrm{g}$ feed & 35 days & $\uparrow \mathrm{LW}$ and FCR & [85] \\
\hline Broiler & $\begin{array}{c}\text { Chicks } \\
\text { (1 day old) }\end{array}$ & $\begin{array}{l}\text { Mixed: } \\
\text { L. bulgaric } \\
\text { L. plantarum } \\
\text { S. faecium } \\
\text { B. Bifidum } \\
\text { S. cerevisiae }\end{array}$ & $\begin{array}{l}100 \mathrm{~g} / \text { ton starter } \\
50 \mathrm{~g} / \text { ton finisher }\end{array}$ & 42 days & $\begin{array}{c}\text { No } \\
\text { improvement }\end{array}$ & [86] \\
\hline Broiler & $\begin{array}{c}\text { Chicks } \\
\text { (1 day old) }\end{array}$ & $\begin{array}{l}\text { Mixed: } \\
\text { L. acidophilus } \\
\text { L. casei } \\
\text { E. faecium } \\
\text { B. thermophilus }\end{array}$ & $10^{9} \mathrm{CFU} / \mathrm{g}$ of feed & 42 days & $\uparrow \mathrm{FI}$ and LW & [87] \\
\hline Layer & $\begin{array}{c}\text { Hens } \\
(15 \text { months } \\
\text { old })\end{array}$ & B. licheniformis & $10^{7} \mathrm{CFU} / \mathrm{g}$ of feed & 12 days & $\begin{array}{c}\uparrow \mathrm{Egg} \\
\text { production }\end{array}$ & [88] \\
\hline Bovine & $\begin{array}{c}\text { Calves } \\
\text { (8 days old) }\end{array}$ & $\begin{array}{l}\text { Single: } \\
\text { L. plantarum GF103 } \\
\text { Mixed: } \\
\text { L. plantarum GF103 } \\
\text { B. subtilis }\end{array}$ & $\begin{array}{c}\text { Oral } \\
1.7 \times 10^{10} \mathrm{CFU} / \text { day } \\
1.7 \times 10^{10} \mathrm{CFU} / \text { day } \\
1.7 \times 10^{8} \mathrm{CFU} / \text { day }\end{array}$ & 83 days & $\begin{array}{c}\uparrow F C R \text { and } C P \\
\text { digestibility }\end{array}$ & [82] \\
\hline Bovine & $\begin{array}{c}\text { Calves } \\
\text { (10 days old) }\end{array}$ & $\begin{array}{c}\text { Mixed: } \\
\text { L. casei DSPV 318T } \\
\text { L. salivarius DSPV 315T } \\
\text { P. acidilactici DSPV 006T }\end{array}$ & $\begin{array}{c}\text { Oral } \\
10^{9} \mathrm{CFU} / \mathrm{kg} \text { LW/day }\end{array}$ & 35 days & $\uparrow \mathrm{LW}$ & [89] \\
\hline Bovine & Dairy cows * & $\begin{array}{c}\text { Mixed: } \\
\text { L. casei Zhang and } L . \\
\text { plantarum } \mathrm{P}-8\end{array}$ & $6.5 \times 10^{10} \mathrm{CFU} /$ day & 30 days & $\begin{array}{c}\uparrow \text { Milk } \\
\text { production }\end{array}$ & [90] \\
\hline Porcine & $\begin{array}{c}\text { Piglets } \\
\text { (36 days old) }\end{array}$ & $\begin{array}{l}\text { Single: } \\
\text { L. plantarum GF103 } \\
\text { Single: } \\
\text { B. subtilis B27 } \\
\text { Mixed: } \\
\text { L. plantarum GF103 } \\
\text { B. subtilis }\end{array}$ & $\begin{array}{l}8.6 \times 10^{9} \mathrm{CFU} / \mathrm{kg} \text { feed } \\
2.0 \times 10^{8} \mathrm{CFU} / \mathrm{kg} \text { feed } \\
4.3 \times 10^{9} \mathrm{CFU} / \mathrm{kg} \text { feed } \\
1.0 \times 10^{8} \mathrm{CFU} / \mathrm{kg} \text { feed }\end{array}$ & 35 days & $\begin{array}{c}\text { All treatments } \\
\uparrow \text { FCR }\end{array}$ & [91] \\
\hline Porcine & $\begin{array}{l}\text { Piglets } \\
\text { (1 month } \\
\text { old })\end{array}$ & $\begin{array}{c}\text { Mixed: } \\
\text { L. reuteri ZJ625 } \\
\text { L. reuteri VB4 } \\
\text { L. salivarius ZJ61 } \\
\text { S. salivarius NBRC } 13956\end{array}$ & $\begin{array}{l}\text { Oral }(10 \mathrm{~mL}) / \text { week. } \\
6.8 \times 10^{9} \mathrm{CFU} / \mathrm{mL} \\
5.5 \times 10^{10} \mathrm{CFU} / \mathrm{mL} \\
5.5 \times 10^{10} \mathrm{CFU} / \mathrm{mL} \\
2.9 \times 10^{10} \mathrm{CFU} / \mathrm{mL}\end{array}$ & 30 days & $\uparrow \mathrm{GP}$ & [92] \\
\hline Porcine & $\begin{array}{c}\text { Piglets } \\
\text { (35 days old) }\end{array}$ & $\begin{array}{l}\text { Mixed: } \\
\text { L. amylovorus } \\
\text { E. faecium }\end{array}$ & $\begin{array}{l}\text { Oral }(3 \mathrm{~mL}) / \text { day } \\
10^{8} \mathrm{CFU} / \mathrm{mL}\end{array}$ & 35 days & $\uparrow \mathrm{FI}$ and FE & [93] \\
\hline
\end{tabular}

FCR = feed conversion ratio; $C P=$ crude protein; $F I=$ feed intake; FE = feed efficiency; LW = live weight; $\mathrm{GP}=$ growth performance; $(\uparrow)$ increase in respective outcome; $\left({ }^{*}\right)$ study did not include age of the animal.

The early postnatal period is thought to be a "critical window" for modifying the gut microbiota as it is the period in which the microbiome is more responsive to internal and external stimuli [40]. This is apparent in germ-free animals bred and kept in a sterile environment in which their immune system is underdeveloped due to lack of exposure to microbes [94]. Jørgensen et al. [42] indicated that the highest sensitivity to probiotic supplementation was seen during the weaning and growing stages of pigs, while it was less effective during the finishing stages. The same study also revealed that probiotic supplementation was most effective when pigs were offered a lower energy diet, which reaffirms the idea that the nutritional status of an animal must be considered when evaluating the efficacy of probiotic supplementation.

The addition of dietary probiotics has also been shown to improve the yield and quality of milk and eggs [52]. The addition of Bacillus subtilis and Bacillus licheniformi significantly improved the fat and protein content of sow's milk during feeding [95]. Similarly, supplementing dairy cows with 
Aspergillus oryzae culture increased the percentage of protein and dry fat-free solids in their milk [96]. Not only does the quality of milk seem to improve when supplemented with probiotics, but several authors have also reported greater milk yield in lactating cows, sows, ewes, and does [95,97-99]. $\mathrm{Xu}$ et al. [90] observed an increase in milk yield by $37 \%$ in dairy cows supplemented with Lactobacillus casei Zhang and Lactobacillus platarum P-8. Alhussien and Dang [100] attributed the increased milk yield in probiotics-supplemented dairy animals to a greater absorption of microbial-derived amino acids and reduced mammary gland inflammation and mastitis. In laying hens, adding the probiotics Bacillus licheniformis and Bacillus subtilis in the diet increased egg production by $3 \%$ and lowered cholesterol levels in egg yolk by 35\% [101]. Furthermore, the inclusion of $10^{7} \mathrm{CFU} / \mathrm{g}$ of probiotic Bacillus licheniformis in laying hen's diet alleviated the adverse effects of heat stress as more egg production, higher feed intake, and better immune response was observed [88].

\section{Probiotics Effect on Meat Quality}

Meat quality is an overarching term that describes traits influencing consumer purchasing decision and eating experience. Such traits include meat color, texture, and water holding capacity (WHC) [102]. These characteristics are influenced throughout the stages of life of an animal, and during harvesting, fabrication, and preparation of the final meat product. In addition to improving animal's growth and production capabilities, probiotics showed a positive effect on quality aspects of both fresh and processed meat products $[103,104]$. Such effects include improvement in product quality and safety, extending shelf-life [105], imparting unique sensory qualities [106], and providing health benefits [105].

Meat color is considered the most important quality attribute in dictating consumers' purchasing decision. This is because consumers use color as an indicator of the overall freshness and wholesomeness of meat products [107]. The variation in meat color is influenced by both pre- and postmortem handling of the animal and carcass and is highly associated with the rate and extent of $\mathrm{pH}$ decline postmortem [108]. Normally, $\mathrm{pH}$ gradually declines from an initial value of 7.2 to an ultimate $\mathrm{pH}$ near 5.6. Abnormal pH decline can lead to defects such as dark, firm, and dry (DFD) meat in which the ultimate $\mathrm{pH}$ remains relatively high $(\mathrm{pH}>6.0)$. In contrast, a rapid decline in $\mathrm{pH}$ while carcass temperature is still high leads to the development of pale, soft, and exudative (PSE) meat defect. In this case, the meat exudes water along with water soluble proteins such as myoglobin, thereby producing a product that has a pale unsavory appearance [109]. In recent years, researchers have explored the potential use of probiotics to improve meat color stability and $\mathrm{pH}$. Zheng et al. [110] reported higher pectoralis major muscle $\mathrm{pH}$ at $45 \mathrm{~min}$ postmortem of broilers that were supplemented with Enterococcus faecium. The increase in $\mathrm{pH}$ was associated with redder pectoralis meat. Similarly, Meng et al. [73] reported darker and redder meat of pigs supplemented with probiotics. The relationship between probiotic supplementation and postmortem $\mathrm{pH}$ decline remains unclear. However, the resulting $\mathrm{pH}$ seems to be influenced by the type of microorganism used and method of administration [111]. Ivanovic et al. [112] showed an increase in breast ultimate $\mathrm{pH}$ of broilers fed with Bacillus cereus IP 5832, whereas a diet containing Streptococcus faecium cernelle 68 was associated with a lower ultimate $\mathrm{pH}$ compared to the control diet. Furthermore, Pelicano et al. [113] indicated differences in ultimate $\mathrm{pH}$ when probiotics were supplemented in the diet compared to drinking water. In totality, by preventing a rapid decline in $\mathrm{pH}$ early postmortem, the use of probiotics could help solving this issue that has been plaguing the pork and poultry industries.

In general, the ability of meat to retain water increases with increasing the ultimate $\mathrm{pH}$ of meat. Within the normal range of ultimate $\mathrm{pH}(5.4-5.8)$, an increase in $\mathrm{pH}$ is often associated with increase in the meat's WHC, which results in a final product that is considered more tender, juicier, and firmer [114]. Evidently, the use of probiotics has been shown to improve WHC and tenderness in meat $[115,116]$. Along with the improvement in tenderness, it was reported by Cramer et al. [117] that the use of probiotic supplementation has the potential to mitigate detrimental defects in meat with animals that have undergone oxidative stress. This notion is supported by studies that showed an increase in antioxidant capacity [118] and reduction in lipid oxidation [119] and reactive oxygen species [120] in 
meats from animals that were supplemented with probiotics. With increasing evidence indicating beneficial effects of probiotics in improving meat quality, researchers have begun to explore other ways to implement these microbes in meat products.

Beyond the benefits on using probiotic cultures in fresh meat products, researchers have recently given attention to using fermented meat products as a carrier of probiotics for human consumption [121]. By using fermented meat as a carrier for these beneficial cultures, there is a prospect of improving human health and inhibiting potential growth of pathogenic and spoilage microorganisms in the food product [122]. Unlike fresh meat products that are usually cooked prior to consumption, processing of fermented meat products requires little to no heat treatment, making them suitable carriers for live cultures [121]. However, the appropriate strain of microbes must be selected in which it could survive the low $\mathrm{pH}$ and water activity and high salt conditions of fermented meat products. The most important probiotic bacteria in fermented meat products are Lactobacilli because of their ability to acidify meat, which contributes to its preservation. Many studies have shown the possibility of using probiotic Lactobacillus strains in fermented meat products such as Lactobacillus plantarum, Lactobacillus curvatus, and Lactobacillus sakei [121]. Erkkilä [123] showed that the use of Lactobacillus rhamnosus GG, Lactobacillus rhamnosus E-97800, and Lactobacillus rhamnosus LC-705 probiotic cultures inhibits E. coli 0157:H7 growth in dry sausage, while at the same time produces high quality sausage that had no adverse effect on technological and sensory properties. In a similar case, Lactobacillus rhamnosus GG showed an inhibitory effect on the growth of Enterobacteriacae during the fermentation process when applied at $10^{5}$ and $10^{7} \mathrm{CFU} / \mathrm{g}$ [124].

In fresh and fermented meat products, lipid oxidation is a major concern as it negatively impacts the sensory quality of the product, and subsequently, its acceptability by the consumer [125]. Free fatty acids are the main precursors for lipid oxidation in fresh and fermented meats $[126,127]$. The potential to use probiotics as protective agents against lipid oxidation comes from their ability to produce bacteriocins that inhibit lipolytic microbes from forming free fatty acids [128,129]. Özer et al. [130] demonstrated that the use of Lactobacillus plantarum at $10^{5} \mathrm{CFU} / \mathrm{kg}$ in fermented sucuk showed significantly lower levels of thiobarbituric acid reactive substances (TBARS), a marker of lipid peroxidation, compared to control samples. A similar conclusion was made by Trabelsi et al. [103] in which lower TBARS were measured in minced meat that was inoculated with Lactobacillus plantarum. Similarly, the addition of Lactobacillus acidophilus and Bifidobacterium lactis in fermented sausage reduced the occurrence of lipid oxidation and contributed to positive organoleptic qualities [131-133].

\section{Conclusions}

Based on this review which summarizes many previous studies, it can be concluded that there are many positive benefits of using probiotics in animal feeding and fresh and processed meat products. Using probiotics seems to improve gut microbiota composition, immune response, nutrient digestibility and absorption, animal growth, and meat quality. Furthermore, many studies showed that probiotics improve the quality of fermented meat products and their sensory properties. Although there were some cases where the use of probiotics in animal feeds and meat products had no clear effect, this sheds some light on the complexity on the use of probiotics. Thus, further studies characterizing specific strains, identifying the optimal dosage, and understanding the network of interactions between probiotics and the gut microbiota could help in formulating more effective probiotic mixtures to be used in animal feed and meat products.

Author Contributions: Conceptualization, S.G.A.-S., D.S.D., and S.K.M.; writing-original draft preparation, S.G.A.-S. and D.S.D.; writing-review and editing, S.G.A.-S., D.S.D., A.Y.Y., Z.K.A.-Y., T.A.N., and S.K.M. All authors have read and agreed to the published version of the manuscript.

Funding: This research received no external funding.

Conflicts of Interest: The authors declare no conflict of interest. 


\section{References}

1. Wicks, J.; Beline, M.; Gomez, J.F.M.; Luzardo, S.; Silva, S.L.; Gerrard, D. Muscle Energy Metabolism, Growth, and Meat Quality in Beef Cattle. Agriculture 2019, 9, 195. [CrossRef]

2. Thornton, P.K. Livestock production: Recent trends, future prospects. Philos. Trans. R. Soc. B Biol. Sci. 2010, 365, 2853-2867. [CrossRef] [PubMed]

3. Duckett, S.; Pratt, S. Meat science and muscle biology symposium-Anabolic implants and meat quality. J. Anim. Sci. 2014, 92, 3-9. [CrossRef] [PubMed]

4. Hao, H.; Cheng, G.; Iqbal, Z.; Ai, X.; Hussain, H.I.; Huang, L.; Dai, M.; Wang, Y.; Liu, Z.; Yuan, Z. Benefits and risks of antimicrobial use in food-producing animals. Front. Microbiol. 2014, 5, 288. [CrossRef]

5. Ronquillo, M.G.; Hernandez, J.C.A. Antibiotic and synthetic growth promoters in animal diets: Review of impact and analytical methods. Food Control 2017, 72, 255-267. [CrossRef]

6. Qu, S.; Kolodziej, E.P.; Cwiertny, D.M. Phototransformation rates and mechanisms for synthetic hormone growth promoters used in animal agriculture. Environ. Sci. Technol. 2012, 46, 13202-13211. [CrossRef]

7. Lipsitch, M.; Singer, R.S.; Levin, B.R. Antibiotics in agriculture: When is it time to close the barn door? Proc. Natl. Acad. Sci. USA 2002, 99, 5752-5754. [CrossRef]

8. Metchnikoff, E. The Prolongation of Life; Putnam: New York, NY, USA, 1908.

9. Majidi-Mosleh, A.; Sadeghi, A.; Mousavi, S.; Chamani, M.; Zarei, A. Ileal MUC2 gene expression and microbial population, but not growth performance and immune response, are influenced by in ovo injection of probiotics in broiler chickens. Br. Poult. Sci. 2017, 58, 40-45. [CrossRef]

10. FAO/WHO. Guidelines for the Evaluation of Probiotics in Food. Report of a Joint FAO/WHO Working Group on Drafting Guidelines for the Evaluation of Probiotics in Food. 2002. Available online: http: //www.who.int/foodsafety/fs_management/en/probiotic_guidelines.pdf (accessed on 9 September 2020).

11. McFarland, L.V. Meta-analysis of probiotics for the prevention of antibiotic associated diarrhea and the treatment of Clostridium difficile disease. Am. J. Gastroenterol. 2006, 101, 812-822. [CrossRef]

12. Hossain, M.; Ko, S.; Kim, G.; Firman, J.; Yang, C. Evaluation of probiotic strains for development of fermented Alisma canaliculatum and their effects on broiler chickens. Poult. Sci. 2012, 91, 3121-3131. [CrossRef]

13. Ezema, C. Probiotics in animal production: A review. J. Vet. Med. Anim. Health 2013, 5, 308-316.

14. Hume, M. Historic perspective: Prebiotics, probiotics, and other alternatives to antibiotics. Poult. Sci. 2011, 90, 2663-2669. [CrossRef] [PubMed]

15. Bomba, A.; Jonecová, Z.; Koščová, J.; Nemcová, R.; Gancarčíková, S.; Mudroňová, D.; Buleca, V.; Lazar, G.; Pošivák, J.; Mareková, M. The improvement of probiotics efficacy by synergistically acting components of natural origin: A review. Biologia 2006, 61, 729-734. [CrossRef]

16. Bomba, A.; Nemcová, R.; Mudroňová, D.; Guba, P. The possibilities of potentiating the efficacy of probiotics. Trends Food Sci. Technol. 2002, 13, 121-126. [CrossRef]

17. Yeoman, C.J.; White, B.A. Gastrointestinal tract microbiota and probiotics in production animals. Annu. Rev. Anim. Biosci. 2014, 2, 469-486. [CrossRef]

18. Beasley, D.E.; Koltz, A.M.; Lambert, J.E.; Fierer, N.; Dunn, R.R. The evolution of stomach acidity and its relevance to the human microbiome. PLoS ONE 2015, 10, e0134116. [CrossRef]

19. Tlaskalová-Hogenová, H.; Štěpánková, R.; Kozáková, H.; Hudcovic, T.; Vannucci, L.; Tučková, L.; Rossmann, P.; Hrnčíř, T.; Kverka, M.; Zákostelská, Z. The role of gut microbiota (commensal bacteria) and the mucosal barrier in the pathogenesis of inflammatory and autoimmune diseases and cancer: Contribution of germ-free and gnotobiotic animal models of human diseases. Cell. Mol. Immunol. 2011, 8 , 110-120. [CrossRef]

20. Czerucka, D.; Piche, T.; Rampal, P. Review article: Yeast as probiotics-Saccharomyces boulardii. Aliment. Pharmacol. 2007, 26, 767-778. [CrossRef]

21. Rajilić-Stojanović, M.; de Vos, W.M. The first 1000 cultured species of the human gastrointestinal microbiota. FEMS Microbiol. Rev. 2014, 38, 996-1047. [CrossRef]

22. Arora, T.; Singh, S.; Sharma, R.K. Probiotics: Interaction with gut microbiome and antiobesity potential. Nutrition 2013, 29, 591-596. [CrossRef]

23. Jami, E.; Israel, A.; Kotser, A.; Mizrahi, I. Exploring the bovine rumen bacterial community from birth to adulthood. ISME J. 2013, 7, 1069-1079. [CrossRef] [PubMed] 
24. Mi, L.; Yang, B.; Hu, X.; Luo, Y.; Liu, J.; Yu, Z.; Wang, J. Comparative analysis of the microbiota between sheep rumen and rabbit cecum provides new insight into their differential methane production. Front. Microbiol. 2018, 9, 575. [CrossRef] [PubMed]

25. Kraimi, N.; Dawkins, M.; Gebhardt-Henrich, S.G.; Velge, P.; Rychlik, I.; Volf, J.; Creach, P.; Smith, A.; Colles, F.; Leterrier, C. Influence of the microbiota-gut-brain axis on behavior and welfare in farm animals: A review. Physiol. Behav. 2019, 210, 112658. [CrossRef]

26. Looft, T.; Johnson, T.A.; Allen, H.K.; Bayles, D.O.; Alt, D.P.; Stedtfeld, R.D.; Sul, W.J.; Stedtfeld, T.M.; Chai, B.; Cole, J.R. In-feed antibiotic effects on the swine intestinal microbiome. Proc. Natl. Acad. Sci. USA 2012, 109, 1691-1696. [CrossRef] [PubMed]

27. Flint, H.J.; Bayer, E.A. Plant cell wall breakdown by anaerobic microorganisms from the mammalian digestive tract. Ann. N. Y. Acad. Sci. 2008, 1125, 280-288. [CrossRef] [PubMed]

28. Moran, J. How the rumen works. Trop. Dairy Farming Landlinks Press Collingwood VIC Aust. 2005, 18, 41-49.

29. Nicholson, J.K.; Holmes, E.; Kinross, J.; Burcelin, R.; Gibson, G.; Jia, W.; Pettersson, S. Host-gut microbiota metabolic interactions. Science 2012, 336, 1262-1267. [CrossRef]

30. Kemgang, T.; Kapila, S.; Shanmugam, V.; Kapila, R. Cross-talk between probiotic lactobacilli and host immune system. J. Appl. Microbiol. 2014, 117, 303-319. [CrossRef]

31. Okumura, R.; Takeda, K. Roles of intestinal epithelial cells in the maintenance of gut homeostasis. Exp. Mol. Med. 2017, 49, e338. [CrossRef]

32. Conlon, M.A.; Bird, A.R. The impact of diet and lifestyle on gut microbiota and human health. Nutrients 2015, 7, 17-44. [CrossRef]

33. Benson, A.K.; Kelly, S.A.; Legge, R.; Ma, F.; Low, S.J.; Kim, J.; Zhang, M.; Oh, P.L.; Nehrenberg, D.; Hua, K. Individuality in gut microbiota composition is a complex polygenic trait shaped by multiple environmental and host genetic factors. Proc. Natl. Acad. Sci. USA 2010, 107, 18933-18938. [CrossRef]

34. Tannock, G.W. What immunologists should know about bacterial communities of the human bowel. Semin. Immunol. 2007, 19, 94-105. [CrossRef] [PubMed]

35. Hildebrandt, M.A.; Hoffmann, C.; Sherrill-Mix, S.A.; Keilbaugh, S.A.; Hamady, M.; Chen, Y.Y.; Knight, R.; Ahima, R.S.; Bushman, F.; Wu, G.D. High-fat diet determines the composition of the murine gut microbiome independently of obesity. Gastroenterology 2009, 137, 1716-1724. [CrossRef] [PubMed]

36. Goodrich, J.K.; Waters, J.L.; Poole, A.C.; Sutter, J.L.; Koren, O.; Blekhman, R.; Beaumont, M.; Van Treuren, W.; Knight, R.; Bell, J.T. Human genetics shape the gut microbiome. Cell 2014, 159, 789-799. [CrossRef] [PubMed]

37. Bonder, M.J.; Kurilshikov, A.; Tigchelaar, E.F.; Mujagic, Z.; Imhann, F.; Vila, A.V.; Deelen, P.; Vatanen, T.; Schirmer, M.; Smeekens, S.P. The effect of host genetics on the gut microbiome. Nat. Genet. 2016, 48, 1407-1412. [CrossRef] [PubMed]

38. Beauchemin, K.; Krehbiel, C.; Newbold, C. Enzymes, bacterial direct-fed microbials and yeast: Principles for use in ruminant nutrition. In Biology of Growing Animals; Elsevier: Amsterdam, The Netherlands, 2006; Volume 4, pp. 251-284.

39. Martín, R.; Miquel, S.; Ulmer, J.; Kechaou, N.; Langella, P.; Bermúdez-Humarán, L.G. Role of commensal and probiotic bacteria in human health: A focus on inflammatory bowel disease. Microb. Cell Fact. 2013, 12, 71. [CrossRef] [PubMed]

40. Mulder, I.E.; Schmidt, B.; Lewis, M.; Delday, M.; Stokes, C.R.; Bailey, M.; Aminov, R.I.; Gill, B.P.; Pluske, J.R.; Mayer, C.-D. Restricting microbial exposure in early life negates the immune benefits associated with gut colonization in environments of high microbial diversity. PLoS ONE 2011, 6, e28279. [CrossRef]

41. Malmuthuge, N.; Guan, L.L. Gut microbiome and omics: A new definition to ruminant production and health. Anim. Front. 2016, 6, 8-12. [CrossRef]

42. Jørgensen, J.N.; Laguna, J.S.; Millán, C.; Casabuena, O.; Gracia, M.I. Effects of a Bacillus-based probiotic and dietary energy content on the performance and nutrient digestibility of wean to finish pigs. Anim. Feed Sci. Technol. 2016, 221, 54-61. [CrossRef]

43. Fuller, R. Probiotics: The Scientific Basis; Springer Science \& Business Media: London, UK, 2012.

44. Rai, V.; Yadav, B.; Lakhani, G. Applications of probiotic and prebiotic in animals production: A review. Environ. Ecol. 2013, 31, 873-876.

45. Abdel-Azeem, M. Do probiotics affect the behavior of turkey poults? J. Vet. Med. Anim. Health 2013, 5, 144-148. 
46. Kabir, S.L.; Rahman, M.; Rahman, M.; Rahman, M.; Ahmed, S. The dynamics of probiotics on growth performance and immune response in broilers. Int. J. Poult. Sci. 2004, 3, 361-364.

47. Bauer, E.; Williams, B.A.; Smidt, H.; Verstegen, M.W.; Mosenthin, R. Influence of the gastrointestinal microbiota on development of the immune system in young animals. Curr. Issues Intest. Microbiol. 2006, 7, 35-52. [PubMed]

48. Jonkers, D.M. Microbial perturbations and modulation in conditions associated with malnutrition and malabsorption. Best Pract. Res. Clin. Gastroenterol. 2016, 30, 161-172. [CrossRef] [PubMed]

49. Chaucheyras-Durand, F.; Durand, H. Probiotics in animal nutrition and health. Benef. Microbes 2010, 1, 3-9. [CrossRef] [PubMed]

50. Parvez, S.; Malik, K.A.; Ah Kang, S.; Kim, H.Y. Probiotics and their fermented food products are beneficial for health. J. Appl. Microbiol. 2006, 100, 1171-1185. [CrossRef] [PubMed]

51. Boirivant, M.; Strober, W. The mechanism of action of probiotics. Curr. Opin. Gastroenterol. 2007, $23,679-692$. [CrossRef]

52. Musa, H.H.; Wu, S.; Zhu, C.; Seri, H.; Zhu, G. The potential benefits of probiotics in animal production and health. J. Anim. Vet. Adv. 2009, 8, 313-321.

53. Ashraf, R.; Shah, N.P. Immune system stimulation by probiotic microorganisms. Crit. Rev. Food Sci. Nutr. 2014, 54, 938-956. [CrossRef]

54. Casas, I.A.; Dobrogosz, W.J. Validation of the probiotic concept: Lactobacillus reuteri confers broad-spectrum protection against disease in humans and animals. Microb. Ecol. Health Dis. 2000, 12, 247-285.

55. Cetin, N.; Güçlü, B.; Cetin, E. The effects of probiotic and mannanoligosaccharide on some haematological and immunological parameters in turkeys. J. Vet. Med. Ser. A 2005, 52, 263-267. [CrossRef] [PubMed]

56. Scharek, L.; Guth, J.; Filter, M.; Schmidt, M.F. Impact of the probiotic bacteria Enterococcus faecium NCIMB 10415 (SF68) and Bacillus cereus var. toyoi NCIMB 40112 on the development of serum IgG and faecal IgA of sows and their piglets. Arch. Anim. Nutr. 2007, 61, 223-234. [CrossRef] [PubMed]

57. Corthésy, B. Multi-faceted functions of secretory IgA at mucosal surfaces. Front. Immunol. 2013, 4, 185. [CrossRef] [PubMed]

58. Yi, Y.; Zhang, Z.; Zhao, F.; Liu, H.; Yu, L.; Zha, J.; Wang, G. Probiotic potential of Bacillus velezensis JW: Antimicrobial activity against fish pathogenic bacteria and immune enhancement effects on Carassius auratus. Fish Shellfish. Immunol. 2018, 78, 322-330. [CrossRef] [PubMed]

59. Chen, C.; Chen, S.; Wang, H. Effect of supplementation of yeast with bacteriocin and Lactobacillus culture on growth performance, cecal fermentation, microbiota composition, and blood characteristics in broiler chickens. Asian Australas. J. Anim. Sci. 2017, 30, 211. [CrossRef]

60. Fuller, R. The importance of lactobacilli in maintaining normal microbial balance in the crop. Br. Poult. Sci. 1977, 18, 85-94. [CrossRef]

61. Francis, C.; Janky, D.; Arafa, A.; Harms, R. Interrelationship of lactobacillus and zinc bacitracin in the diets of turkey poults. Poult. Sci. 1978, 57, 1687-1689. [CrossRef]

62. Hardy, H.; Harris, J.; Lyon, E.; Beal, J.; Foey, A.D. Probiotics, prebiotics and immunomodulation of gut mucosal defences: Homeostasis and immunopathology. Nutrients 2013, 5, 1869-1912. [CrossRef]

63. Van Coillie, E.; Goris, J.; Cleenwerck, I.; Grijspeerdt, K.; Botteldoorn, N.; Van Immerseel, F.; De Buck, J.; Vancanneyt, M.; Swings, J.; Herman, L. Identification of lactobacilli isolated from the cloaca and vagina of laying hens and characterization for potential use as probiotics to control Salmonella Enteritidis. J. Appl. Microbiol. 2007, 102, 1095-1106. [CrossRef]

64. Ramasamy, K.; Abdullah, N.; Jalaludin, S.; Wong, M.; Ho, Y.W. Effects of Lactobacillus cultures on performance of laying hens, and total cholesterol, lipid and fatty acid composition of egg yolk. J. Sci. Food Agric. 2009, 89, 482-486. [CrossRef]

65. Liu, H.; Zhang, J.; Zhang, S.; Yang, F.; Thacker, P.A.; Zhang, G.; Qiao, S.; Ma, X. Oral administration of Lactobacillus fermentum 15007 favors intestinal development and alters the intestinal microbiota in formula-fed piglets. J. Agric. Food Chem. 2014, 62, 860-866. [CrossRef] [PubMed]

66. Peterson, R.; Klopfenstein, T.J.; Erickson, G.E.; Folmer, J.; Hinkley, S.; Moxley, R.A.; Smith, D.R. Effect of Lactobacillus acidophilus strain NP51 on Escherichia coli O157: H7 fecal shedding and finishing performance in beef feedlot cattle. J. Food Prot. 2007, 70, 287-291. [CrossRef] [PubMed]

67. Nikoskelainen, S.; Ouwehand, A.; Salminen, S.; Bylund, G. Protection of rainbow trout (Oncorhynchus mykiss) from furunculosis by Lactobacillus rhamnosus. Aquaculture 2001, 198, 229-236. [CrossRef] 
68. Candela, M.; Perna, F.; Carnevali, P.; Vitali, B.; Ciati, R.; Gionchetti, P.; Rizzello, F.; Campieri, M.; Brigidi, P. Interaction of probiotic Lactobacillus and Bifidobacterium strains with human intestinal epithelial cells: Adhesion properties, competition against enteropathogens and modulation of IL-8 production. Int. J. Food Microbiol. 2008, 125, 286-292. [CrossRef]

69. Lebeer, S.; Vanderleyden, J.; De Keersmaecker, S.C. Genes and molecules of lactobacilli supporting probiotic action. Microbiol. Mol. Biol. Rev. 2008, 72, 728-764. [CrossRef] [PubMed]

70. Vélez, M.P.; De Keersmaecker, S.C.; Vanderleyden, J. Adherence factors of Lactobacillus in the human gastrointestinal tract. FEMS Microbiol. Lett. 2007, 276, 140-148. [CrossRef] [PubMed]

71. Gerrard, D.E.; Grant, A.L. Principles of Animal Growth and Development; Kendall Hunt: Dubuque, IA, USA, 2003.

72. Owens, F.N.; Dubeski, P.; Hanson, C. Factors that alter the growth and development of ruminants. J. Anim. Sci. 1993, 71, 3138-3150. [CrossRef]

73. Meng, Q.; Yan, L.; Ao, X.; Zhou, T.; Wang, J.; Lee, J.; Kim, I. Influence of probiotics in different energy and nutrient density diets on growth performance, nutrient digestibility, meat quality, and blood characteristics in growing-finishing pigs. J. Anim. Sci. 2010, 88, 3320-3326. [CrossRef]

74. Jäger, R.; Purpura, M.; Farmer, S.; Cash, H.A.; Keller, D. Probiotic Bacillus coagulans GBI-30, 6086 improves protein absorption and utilization. Probiotics Antimicrob. Proteins 2018, 10, 611-615. [CrossRef]

75. Onifade, A.; Babatunde, G.; Afonja, S.; Ademola, S.; Adesina, E. The effect of a yeast culture addition to a low-protein diet on the performance and carcass characteristics of broiler chickens. Poult. Sci. 1998, 77, 44.

76. Kumprechtova, D.; Zobač, P.; Kumprecht, I. The effect of Saccharomyces cerevisiae Sc47 on chicken broiler performance and nitrogen output. Czech J. Anim. Sci. 2000, 45, 169-177.

77. Midilli, M.; Alp, M.; Kocabach, N.; Muglah, O.; Turan, N.; Yilmaz, H.; Cakir, S. Effects of dietary probiotic and prebiotic supplementation on growth performance and serum IgG concentration of broilers. S. Afr. J. Anim. Sci. 2008, 38, 21-27. [CrossRef]

78. Gao, J.; Zhang, H.; Yu, S.; Wu, S.; Yoon, I.; Quigley, J.; Gao, Y.; Qi, G. Effects of yeast culture in broiler diets on performance and immunomodulatory functions. Poult. Sci. 2008, 87, 1377-1384. [CrossRef] [PubMed]

79. Abe, F.; Ishibashi, N.; Shimamura, S. Effect of administration of bifidobacteria and lactic acid bacteria to newborn calves and piglets. J. Dairy Sci. 1995, 78, 2838-2846. [CrossRef]

80. Adams, M.; Luo, J.; Rayward, D.; King, S.; Gibson, R.; Moghaddam, G. Selection of a novel direct-fed microbial to enhance weight gain in intensively reared calves. Anim. Feed Sci. Technol. 2008, 145, 41-52. [CrossRef]

81. Ran, T.; Gomaa, W.; Shen, Y.; Saleem, A.; Yang, W.; McAllister, T. Use of naturally sourced feed additives (lactobacillus fermentation products and enzymes) in growing and finishing steers: Effects on performance, carcass characteristics and blood metabolites. Anim. Feed Sci. Technol. 2019, 254, 114190. [CrossRef]

82. Zhang, R.; Zhou, M.; Tu, Y.; Zhang, N.; Deng, K.; Ma, T.; Diao, Q. Effect of oral administration of probiotics on growth performance, apparent nutrient digestibility and stress-related indicators in Holstein calves. J. Anim. Physiol. Anim. Nutr. 2016, 100, 33-38. [CrossRef]

83. Timmerman, H.; Mulder, L.; Everts, H.; Van Espen, D.; Van Der Wal, E.; Klaassen, G.; Rouwers, S.; Hartemink, R.; Rombouts, F.; Beynen, A. Health and growth of veal calves fed milk replacers with or without probiotics. J. Dairy Sci. 2005, 88, 2154-2165. [CrossRef]

84. Spanhaak, S.; Havenaar, R.; Schaafsma, G. The effect of consumption of milk fermented by Lactobacillus casei strain Shirota on the intestinal microflora and immune parameters in humans. Eur. J. Clin. Nutr. 1998, 52, 899-907. [CrossRef]

85. Ramlucken, U.; Ramchuran, S.O.; Moonsamy, G.; Lalloo, R.; Thantsha, M.S.; van Rensburg, C.J. A novel Bacillus based multi-strain probiotic improves growth performance and intestinal properties of Clostridium perfringens challenged broilers. Poult. Sci. 2020, 99, 331-341. [CrossRef]

86. Sarangi, N.R.; Babu, L.; Kumar, A.; Pradhan, C.; Pati, P.; Mishra, J. Effect of dietary supplementation of prebiotic, probiotic, and synbiotic on growth performance and carcass characteristics of broiler chickens. Vet. World 2016, 9, 313. [CrossRef] [PubMed]

87. Cengiz, Ö.; Köksal, B.H.; Tatlı, O.; Sevim, Ö.; Ahsan, U.; Üner, A.G.; Ulutaş, P.A.; Beyaz, D.; Büyükyörük, S.; Yakan, A. Effect of dietary probiotic and high stocking density on the performance, carcass yield, gut microflora, and stress indicators of broilers. Poult. Sci. 2015, 94, 2395-2403. [CrossRef] [PubMed] 
88. Deng, W.; Dong, X.; Tong, J.; Zhang, Q. The probiotic Bacillus licheniformis ameliorates heat stress-induced impairment of egg production, gut morphology, and intestinal mucosal immunity in laying hens. Poult. Sci. 2012, 91, 575-582. [CrossRef] [PubMed]

89. Frizzo, L.; Soto, L.; Zbrun, M.; Bertozzi, E.; Sequeira, G.; Armesto, R.R.; Rosmini, M. Lactic acid bacteria to improve growth performance in young calves fed milk replacer and spray-dried whey powder. Anim. Feed Sci. Technol. 2010, 157, 159-167. [CrossRef]

90. Xu, H.; Huang, W.; Hou, Q.; Kwok, L.-Y.; Sun, Z.; Ma, H.; Zhao, F.; Lee, Y.-K.; Zhang, H. The effects of probiotics administration on the milk production, milk components and fecal bacteria microbiota of dairy cows. Sci. Bull. 2017, 62, 767-774. [CrossRef]

91. Dong, X.; Zhang, N.; Zhou, M.; Tu, Y.; Deng, K.; Diao, Q. Effects of dietary probiotics on growth performance, faecal microbiota and serum profiles in weaned piglets. Anim. Prod. Sci. 2014, 54, 616-621. [CrossRef]

92. Dlamini, Z.; Langa, R.; Aiyegoro, O.; Okoh, A. Effects of probiotics on growth performance, blood parameters, and antibody stimulation in piglets. S. Afr. J. Anim. Sci. 2017, 47, 765-776. [CrossRef]

93. Ross, G.R.; Gusils, C.; Oliszewski, R.; De Holgado, S.C.; González, S.N. Effects of probiotic administration in swine. J. Biosci. Bioeng. 2010, 109, 545-549. [CrossRef]

94. Macpherson, A.J.; Geuking, M.B.; McCoy, K.D. Immune responses that adapt the intestinal mucosa to commensal intestinal bacteria. Immunology 2005, 115, 153-162. [CrossRef]

95. Alexopoulos, C.; Georgoulakis, I.; Tzivara, A.; Kritas, S.; Siochu, A.; Kyriakis, S. Field evaluation of the efficacy of a probiotic containing Bacillus licheniformis and Bacillus subtilis spores, on the health status and performance of sows and their litters. J. Anim. Physiol. Anim. Nutr. 2004, 88, 381-392. [CrossRef]

96. Yu, P.; Huber, J.; Theurer, C.; Chen, K.; Nussio, L.; Wu, Z. Effect of steam-flaked or steam-rolled corn with or without Aspergillus oryzae in the diet on performance of dairy cows fed during hot weather. J. Dairy Sci. 1997, 80, 3293-3297. [CrossRef]

97. Ma, Z.Z.; Cheng, Y.Y.; Wang, S.Q.; Ge, J.Z.; Shi, H.P.; Kou, J.C. Positive effects of dietary supplementation of three probiotics on milk yield, milk composition and intestinal flora in Sannan dairy goats varied in kind of probiotics. J. Anim. Physiol. Anim. Nutr. 2020, 104, 44-55. [CrossRef] [PubMed]

98. Vibhute, V.; Shelke, R.; Chavan, S.; Nage, S. Effect of probiotics supplementation on the performance of lactating crossbred cows. Vet. World 2011, 4, 557. [CrossRef]

99. Kritas, S.; Govaris, A.; Christodoulopoulos, G.; Burriel, A. Effect of Bacillus licheniformis and Bacillus subtilis supplementation of ewe's feed on sheep milk production and young lamb mortality. J. Vet. Med. Ser. A 2006, 53, 170-173. [CrossRef]

100. Alhussien, M.N.; Dang, A.K. Milk somatic cells, factors influencing their release, future prospects, and practical utility in dairy animals: An overview. Vet. World 2018, 11, 562. [CrossRef]

101. Kurtoglu, V.; Kurtoglu, F.; Seker, E.; Coskun, B.; Balevi, T.; Polat, E. Effect of probiotic supplementation on laying hen diets on yield performance and serum and egg yolk cholesterol. Food Addit. Contam. 2004, 21, 817-823. [CrossRef]

102. Maltin, C.; Balcerzak, D.; Tilley, R.; Delday, M. Determinants of meat quality: Tenderness. Proc. Nutr. Soc. 2003, 62, 337-347. [CrossRef]

103. Trabelsi, I.; Slima, S.B.; Ktari, N.; Triki, M.; Abdehedi, R.; Abaza, W.; Moussa, H.; Abdeslam, A.; Salah, R.B. Incorporation of probiotic strain in raw minced beef meat: Study of textural modification, lipid and protein oxidation and color parameters during refrigerated storage. Meat Sci. 2019, 154, 29-36. [CrossRef]

104. Bis-Souza, C.V.; Penna, A.L.B.; da Silva Barretto, A.C. Applicability of potentially probiotic Lactobacillus casei in low-fat Italian type salami with added fructooligosaccharides: In vitro screening and technological evaluation. Meat Sci. 2020, 168, 108186. [CrossRef]

105. Kumar, P.; Chatli, M.; Verma, A.K.; Mehta, N.; Malav, O.; Kumar, D.; Sharma, N. Quality, functionality, and shelf life of fermented meat and meat products: A review. Crit. Rev. Food Sci. Nutr. 2017, 57, 2844-2856. [CrossRef]

106. Rouhi, M.; Sohrabvandi, S.; Mortazavian, A. Probiotic fermented sausage: Viability of probiotic microorganisms and sensory characteristics. Crit. Rev. Food Sci. Nutr. 2013, 53, 331-348. [CrossRef] [PubMed]

107. Mancini, R.; Hunt, M. Current research in meat color. Meat Sci. 2005, 71, 100-121. [CrossRef] [PubMed]

108. Matarneh, S.K.; England, E.M.; Scheffler, T.L.; Gerrard, D.E. The conversion of muscle to meat. In Lawrie's Meat Science; Elsevier: Amsterdam, The Netherlands, 2017; pp. 159-185. 
109. Chmiel, M.; Słowiński, M.; Dasiewicz, K. Lightness of the color measured by computer image analysis as a factor for assessing the quality of pork meat. Meat Sci. 2011, 88, 566-570. [CrossRef] [PubMed]

110. Zheng, A.; Luo, J.; Meng, K.; Li, J.; Zhang, S.; Li, K.; Liu, G.; Cai, H.; Bryden, W.L.; Yao, B. Proteome changes underpin improved meat quality and yield of chickens (Gallus gallus) fed the probiotic Enterococcus faecium. BMC Genom. 2014, 15, 1167. [CrossRef]

111. Popova, T. Effect of probiotics in poultry for improving meat quality. Curr. Opin. Food Sci. 2017, 14, 72-77. [CrossRef]

112. Ivanovic, S.; Pisinov, B.; Savic, D.M.-S.B.; Stojanovic, Z. Influence of probiotics on quality of chicken meat. Afr. J. Agric. Res. 2012, 7, 2191-2196.

113. Pelicano, E.R.L.; De Souza, P.; De Souza, H.; Oba, A.; Norkus, E.; Kodawara, L.; De Lima, T. Effect of different probiotics on broiler carcass and meat quality. Braz. J. Poult. Sci. 2003, 5, 207-214. [CrossRef]

114. Huff-Lonergan, E.; Lonergan, S.M. Mechanisms of water-holding capacity of meat: The role of postmortem biochemical and structural changes. Meat Sci. 2005, 71, 194-204. [CrossRef]

115. Zhou, X.; Wang, Y.; Gu, Q.; Li, W. Effect of dietary probiotic, Bacillus coagulans, on growth performance, chemical composition, and meat quality of Guangxi Yellow chicken. Poult. Sci. 2010, 89, 588-593. [CrossRef]

116. Liu, L.; Ni, X.; Zeng, D.; Wang, H.; Jing, B.; Yin, Z.; Pan, K. Effect of a dietary probiotic, Lactobacillus johnsonii BS15, on growth performance, quality traits, antioxidant ability, and nutritional and flavour substances of chicken meat. Anim. Prod. Sci. 2017, 57, 920-926. [CrossRef]

117. Cramer, T.; Kim, H.; Chao, Y.; Wang, W.; Cheng, H.; Kim, Y. Effects of probiotic (Bacillus subtilis) supplementation on meat quality characteristics of breast muscle from broilers exposed to chronic heat stress. Poult. Sci. 2018, 97, 3358-3368. [CrossRef]

118. Bai, K.; Huang, Q.; Zhang, J.; He, J.; Zhang, L.; Wang, T. Supplemental effects of probiotic Bacillus subtilis $\mathrm{fmbJ}$ on growth performance, antioxidant capacity, and meat quality of broiler chickens. Poult. Sci. 2017, 96, 74-82. [CrossRef] [PubMed]

119. Kim, H.; Yan, F.; Hu, J.; Cheng, H.; Kim, Y. Effects of probiotics feeding on meat quality of chicken breast during postmortem storage. Poult. Sci. 2016, 95, 1457-1464. [CrossRef] [PubMed]

120. Bai, W.K.; Zhang, F.J.; He, T.J.; Su, P.W.; Ying, X.Z.; Zhang, L.L.; Wang, T. Dietary probiotic Bacillus subtilis strain fmbj increases antioxidant capacity and oxidative stability of chicken breast meat during storage. PLoS ONE 2016, 11, e0167339. [CrossRef] [PubMed]

121. De Vuyst, L.; Falony, G.; Leroy, F. Probiotics in fermented sausages. Meat Sci. 2008, 80, 75-78. [CrossRef]

122. Sidira, M.; Karapetsas, A.; Galanis, A.; Kanellaki, M.; Kourkoutas, Y. Effective survival of immobilized Lactobacillus casei during ripening and heat treatment of probiotic dry-fermented sausages and investigation of the microbial dynamics. Meat Sci. 2014, 96, 948-955. [CrossRef]

123. Erkkilä, S. Bioprotective and Probiotic Meat Starter Cultures for the Fermentation of Dry Sausages. Ph.D. Dissertation, University of Helsinki, Helsinki, Finland, 2001.

124. Rubio, R.; Aymerich, T.; Bover-Cid, S.; Guàrdia, M.D.; Arnau, J.; Garriga, M. Probiotic strains Lactobacillus plantarum $299 \mathrm{~V}$ and Lactobacillus rhamnosus GG as starter cultures for fermented sausages. LWT Food Sci. Technol. 2013, 54, 51-56. [CrossRef]

125. Love, J.D.; Pearson, A. Lipid oxidation in meat and meat products-A review. J. Am. Oil Chem. Soc. 1971, 48, 547-549. [CrossRef]

126. Gianelli, M.P.; Salazar, V.; Mojica, L.; Friz, M. Volatile compounds present in traditional meat products (charqui and longaniza sausage) in Chile. Braz. Arch. Biol. Technol. 2012, 55, 603-612. [CrossRef]

127. Slima, S.B.; Ktari, N.; Triki, M.; Trabelsi, I.; Abdeslam, A.; Moussa, H.; Makni, I.; Herrero, A.M.; Jiménez-Colmenero, F.; Ruiz-Capillas, C. Effects of probiotic strains, Lactobacillus plantarum TN8 and Pediococcus acidilactici, on microbiological and physico-chemical characteristics of beef sausages. LWT 2018, 92, 195-203. [CrossRef]

128. Smaoui, S.; Ennouri, K.; Chakchouk-Mtibaa, A.; Karray-Rebai, I.; Hmidi, M.; Bouchaala, K.; Mellouli, L. Relationships between textural modifications, lipid and protein oxidation and sensory attributes of refrigerated turkey meat sausage treated with bacteriocin BacTN635. Food Bioprocess Technol. 2017, 10, 1655-1667. [CrossRef]

129. Smaoui, S.; Elleuch, L.; Ben Salah, R.; Najah, S.; Chakchouk-Mtibaa, A.; Sellem, I.; Besbes, S.; Mellouli, L. Efficient role of BacTN635 on the safety properties, sensory attributes, and texture profile of raw minced meat beef and chicken breast. Food Addit. Contam. Part A 2014, 31, 218-225. [CrossRef] [PubMed] 
130. Özer, C.O.; Kılıç, B.; Kılıç, G.B. In-vitro microbial production of conjugated linoleic acid by probiotic L. plantarum strains: Utilization as a functional starter culture in sucuk fermentation. Meat Sci. 2016, 114, 24-31. [CrossRef] [PubMed]

131. Amanatidou, A.; Smid, E.J.; Bennik, M.H.; Gorris, L.G. Antioxidative properties of Lactobacillus sake upon exposure to elevated oxygen concentrations. FEMS Microbiol. Lett. 2001, 203, 87-94. [CrossRef] [PubMed]

132. Talon, R.; Leroy, S.; Lebert, I. Microbial ecosystems of traditional fermented meat products: The importance of indigenous starters. Meat Sci. 2007, 77, 55-62. [CrossRef]

133. Simion, A.M.C.; Vizireanu, C.; Alexe, P.; Franco, I.; Carballo, J. Effect of the use of selected starter cultures on some quality, safety and sensorial properties of Dacia sausage, a traditional Romanian dry-sausage variety. Food Control 2014, 35, 123-131. [CrossRef]

(C) 2020 by the authors. Licensee MDPI, Basel, Switzerland. This article is an open access article distributed under the terms and conditions of the Creative Commons Attribution (CC BY) license (http://creativecommons.org/licenses/by/4.0/). 